\title{
TOWARD A WISE POLITICAL FIQH: THE PERCEPTION OF STATE IN THE POLITICAL THOUGHT OF YUSUF AL-QARADAWI*
}

\author{
Akı1lı Bir Siyasi Fıkh'a Doğru: Yusuf El-Karadavi'nin Siyasi Düşüncesinde \\ Devlet Algisı
}

Hafijur RAHMAN ${ }^{1}$

\begin{abstract}
ÖZET
$\mathrm{Bu}$ araştırma, çağdaş dünyadaki en önde gelen Müslüman Âlimlerden biri olan Yusuf el-Karadavi'nin siyasi düşüncesini incelemektedir. El-Karadavi, İslami hareketlerin ve İslamcı siyasi partilerin önemli teorisyeni olarak kabul edilmektedir. Aşırılığın öne çıktığı Seyyid Kutub döneminden sonra Müslüman Kardeşler'in ikinci neslinin siyasi düşüncesini oluşturmada büyük bir katkısı vardır. Genellikle Vasatiyyah düşünce okulunun teorisyeni olarak kabul edilmektedir. El-Karadavi, esnek İslami şeriat hedefine yönelik yazıları 1şığında şimdiki zaman, çevre ve şartlarla ilgili "akı1lı bir F1kıh (anlayış)"1 geliştirmeyi amaçlanmıştır. Ayrıca olumsuz siyasi F1kıh konusunda ilgilenmiş ve İslami hareketlerin çalışmalarında ve politikalarında bu olumsuz ideolojileri reddetmelerini tavsiye etmiştir. Bunu takıben, akıllı siyasi Fıkıh'a dayalı bir İslami devleti öne çıkarmıştır. Onun İslam devleti algısı, modern devlet terimlerine, yani demokrasi, çoğulculuk, yasama meclisine kadınların katılımı vb. olumlu bir yaklaşımı vermektedir. Bu makale genel olarak onun devlet kavramını ve özel olarak akıllı bir siyasi Fıkhı ile ilgili düşüncesini tartışacaktır. Bu araştırma, büyük ölçüde birincil veriler ve bazı bağlamlarda ikincil verilere dayanan nitel bir içerik araştırmasıdır. Birincil veriler, el-Karadavi'nin devlet ile ilgili yazılarından, ikincil veriler el-Karadavi'nin siyasal düşüncesi üzerine yazılmış metinlerden toplanmışıtır.
\end{abstract}

Anahtar Kelimeler: El-Karadavi, Siyasi F1kıh, İslam Devleti, Demokrasi, İslami Siyasal Düşünce

\begin{abstract}
This research examines the political thought of Yusuf alQaradawi, who is one of the prominent Muslim scholars in the contemporary world. In particular, he considered the vital theorist of Islamic movements and Islamist political parties. He has a massive contribution in forming political thought of the second generation of the Muslim Brotherhood after Sayyid Qutb's period when the extremism came in front. He is often regarded as the theorist of the Wasatiyyah school of thought. Al-Qaradawi intended to develop a "wise political Fiqh (understanding)" concerning current time, environment, and circumstances in the light of overall text toward an objective of flexible Islamic Shari'ah. He was also concerned about the negative political Fiqh and advised the Islamic movement to reject these negative ideologies in their works and politics. Following this concern, he featured an Islamic state based on wise political Fiqh. His perception of the Islamic state positively approaches modern state terms, i.e., democracy, pluralism, women participation in the legislative council, etc. This paper discusses his concept of state in general and his thought toward a wise political Fiqh in particular. This research is a qualitative content research based on primary data at a large and secondary data in some context. Primary data was collected from the alQaradawi's text on state, where secondary data were collected from the texts written on al-Qaradawi's political thought.
\end{abstract}

Keywords: Al-Qaradawi, Political Fiqh, Islamic state, Democracy, Islamic Political Thought 


\section{GENIŞLETILMIŞ ÖZET}

İslam devleti kavramı günümüzde hem önemli hem de tartışmalı bir konu hale geldi, özellikle IŞID'in veya tüm dünyada birkaç aşırılıkçı grubun yükselişinde; bu kavram, akademide daha önem kazanmıştır. Laik entelektüeller İslam'da siyaset veya devletle hiçbir şey olmadığını iddia ederken birkaç grup İslam devletini kendi bakış açılarından tanımlamak istemiştir. Öte yandan, bazı aşırılık yanlışı gruplar aşırılıkçı bir yol izleyerek İslami bir devlet kurmaya amaçlanmıştır. Bu iki grup dışında, İslami devlet kavramı etrafında da birkaç tartışma daha vardır, özellikle modern devlet kavramları, yani demokrasi, çoğulculuk, kadınların katılımı vb. gibi konularda tartışmalar vardır. Yusuf el-Karadavi İslami konularda uzun süredir entelektüel katkısı veren Katar merkezli Mısırlı bir entelektüeldir. Ancak, özellikle Fıkıh konusunda İslami araştırmaları uzmanı olmasına rağmen siyasete onun katkısı önemlidir. Özelikle İslami hareketlerin ve İslamcı siyasi partilerin en etkili teorisyeni olarak kabul edilmektedir. Bu araştırma Yusuf el-Karadavi'nin siyasi şaheseri olan İslam'da Devlet Mefhumu'nda belirttiği akıllı siyasi Fıkıh'ı göz önünde bulundurarak devlet algısını analiz etmeyi amaçlanmıştır. Bu kitapta, İslam devletinin algısındaki birkaç olumsuz düşünceyi tespit etmeyi amaçlanmış: özellikle Yargılama Fıkıhı, Zahiri Fıkıh, Hariji Fıkıh ve Geleneksel Fıkıh ile ilgilidir. Bu olumsuz F1kıhlar hakkında ayrıntılara değinen Karadavi, mevcut zamanı, ortamı ve koşulları göz önünde bulundurarak olumlu ve akıllıca bir siyasi Fıkıh geliştirmeyi çalışmıştır. Genel metni esnek bir İslami Şeriat hedefine doğru ele almakla ilgilenmiştir. Bu konuda, Fıkıh ile ilgili Bidat gibi birçok meseleyi siyasete yaklaştırmayı amaçlanmıştır. Siyasi icadın bir Bidat olmadığını savunarak bunun yerine bu zamanda gerekli olduğunu ve Bidat yalnızca din odaklı ibadetle ilgili olduğunu savunmuştur. Bu yönleriyle, Hulefâ-yi Râşidîn döneminden birkaç örnek vermiştir. Bunun yanı sıra, gündelik işleriyle (normal hayat) ile ilgili olan Peygamberin hayatının sünnet ile aynı olmadığın, bunun benzar bir şeyin sünnet olabilmesi için başka bir metinle (hadis) gerekçelendirilmesi gerektiğini ileri sürmeyi amaçlamıştır. Bu konuları takiben, siyasi Fıkıh'1 geliştirmek için dünyanın şimdiki zamanını ve bugünkü gerçeklerini dikkate alması gerektiğini vurgulamıştır. Yeni siyasi fıkıhı yani Sunan F1kıhı, Hedefler F1kıhı, Denge Fıkıhı, Öncelik Fıkı1ı ve Farklılık Fıkıhı leri modern zamanda başlatılması gerektiğini vurgulamıştır. Bu olumlu siyasi F1kıh içinde, İslami normları, değerleri ve ahlakı olan sivil bir devlet olarak bir İslam devletini öne çıkarmıştır. İslam devletinin asla, modern öncesi dönemlerde Avrupa Hristiyan devleti gibi yönetime liderlik etme çalışmalarında dini liderlerin egemen olduğu ilahi bir devlet olmadığını savunmuştur. Ona göre İslam devleti, Ümmet kavramı kapsamında küresel bir devlettir, ama bu bir ulus devlet ile başlatmasında bir sakıncası yoktur. Modern devlete, İslami değerlerin eğilimlerine karşı çıkmayan iyi şeyleri, fikirleri ve kavramları kabul etme konusunda olumlu bir bakış açısıyla yaklaşmıştır. Bu bakış açısıyla, demokrasiye, çoğulculuğa ve Kadınların ve Gayrimüslimlerin parlamentoya katılımına olumlu tavır göstermiştir. Öte yandan laik iddiaları reddetti ve İslam'ın siyasi yönu olması gerektiğini belirtmiştir. Metinden, tarihinden ve İslam'ın doğasından çeşitli kanıtları tartışarak, İslam devletinin 7. yüzyıldan 20. yüzyıla kadar varlığını kanıtlamayı amaçlanmıştır. Bu makale onun İslam devleti algısının ana odağı olarak kabul edilen akıllı siyasi 
F1kıh kavramını incelemektedir. Bunun yanı sıra, Karadavi’nin siyası düşüncesinin farklı yönlerini ve onun demokrasi ve çoğulculuğa yaklaşımını da tartışacaktır.

\section{Introduction}

The concept of the Islamic state has become an important as well as controversial topic in contemporary time, particularly within the rise of ISIS or several extremist groups all over the world; this concept has become more controversial in academia. This research found different aspects of thinking on Islamic state, from them five are more common in everywhere of the world: firstly, the secularist groups intend to identify that in Islam, there is nothing about state: secondly, the particular western as well as Muslim intellectual who intends to compare the concept of Islamic state with extremism and terrorism; thirdly, a group of Muslims who think that Islamic state means government by traditional Ulama (Islamic scholar) and implementing Shari'ah only: fourthly, the Islamic extremist groups intend to establish Islamic state in an extremist way, generally they use 'Jihad' in a negative perspective and finally, the Islamist movements and parties intend to establish Islamic state in a democratic way though they usually divided by two groups in terms of thinking as main-stream and reformist; the main-stream Islamist parties are in the thought of establishing caliphate focusing the classical form of Islamic state where reformist parties are in the thought of establishing state accepting the aspects of Western thought within Islamic norms and values though they are often criticized by main-stream parties for becoming far from Islamic norms and values.

Yusuf al-Qaradawi, a Qatar based Egyptian intellectual who has a long intellectual contribution regarding Islamic issues. Though he is an expert in Islamic studies, especially in Fiqh (Islamic Jurisprudence), his contribution to politics is significant in academia. He considered the most influential theorist of Islamic movements and Islamist political parties. Existing literature on al-Qaradawi provided a significant study on his works, particularly of Wasatiyyah scholar and his importance in the Islamic thought. Soage (2008) considered him a leading Islamic cleric, where Warren (2004: 2014) considered the global Mufti. Wardeh (2001) and El Mahdy (2015) significantly discussed his thought in the perspective of Wasatiyyah and his contribution toward making the thought of the second generation of the Muslim Brotherhood. Baroudi (2014) analyzed al-Qaradawi's contribution to international relations within the Islamic world views where Wasati's idea shaped the thought. Bartal (2015) examined his contribution toward reconciling between Fatah and Hamas though many pro-Israel researchers considered him the enemy of Israel. Other existing works on al-Qaradawi mainly analyzed his theological works.

This research intended to analyze his perception of state considering his wise political Fiqh, which he stated basically in his masterpiece on politics, State in Islam. In this book, he intended to identify several negative thinking of all those five groups. He refused the secularist claims and stated, "Islam must be political" (al-Qaradawi, 2004: 123). By several proofs from text, history, and the nature of Islam, he intended to prove the existence of Islamic state during the 7th century to the 20th century. Al-Qaradawi intended to develop a positive and wise political Fiqh considering 
the present time, environment, and circumstances. He was concerned to consider overall text toward an objective of flexible Islamic Shari'ah. He featured of Islamic state as a civilian state with Islamic norms, values, and morals. He argued that the Islamic state is a global state within the Ummah's concept, but nothing prohibited it to start within a nation state. He approached the modern state with a positive view of accepting good things, ideas and concepts that do not oppose the trends of Islamic values. Within this viewpoint, he responded democracy, pluralism, participation of Women and non-Muslim in the parliament in a positive way. This paper examines his concept of wise political Fiqh, which was considered his main focus of the perception of the Islamic state. This paper will discuss the different aspects of al-Qaradawi's thought as well as his approach toward democracy and pluralism with a short biographical overview.

\section{Methodological Overview}

Content analysis is one of the famous research methods in social science which analyzes the text, verbal and visual communication massage for understanding the real message of the writer and sender. It aims to build a model to describe the phenomenon in a conceptual form (Elo and Kynga, 2008: 107). Krippendorff defined content analysis as "a research technique for making replicable and valid inferences from texts (or other meaningful matter) to the contexts of their use" (Krippendorff, 2004: 18). This research is mostly based on primary data. Within the aspect of content analysis, the text of Yusuf al-Qaradawi on the concept of state, "State in Islam", was analyzed as a primary data. So, a massive discussion of this paper is based on this primary data. Along with this, some texts and other secondary materials on al-Qaradawi's thought as secondary data were also analyzed to understand his concept of state and especially his political Fiqh. This research also included the biographical statement of al-Qaradawi in a short pattern to understand his intellectual background.

\section{A Short Biography of Yusuf al-Qaradawi}

Yusuf al-Qaradawi was born on 9th September, 1926 in the village of Safat Turab, belonging to Mahallah al-Kubra in Egypt. He was the only child of his religious family where his father died when he was two. His maternal uncle looked his interest after father's death. He enrolled in a local kuttab (religious school) in his early age and memorized the Quran at nine. From his childhood, he had an intention to acquire religious knowledge in a depth way. He regularly joined the lectures of religious scholars and shaykhs in the village that influenced him to continue his education at alAzhar University (Wardeh, 2001: 8). He enrolled at Ma'had Tanta al Dini (the religious institute of Tanta), one of schools affiliated to the al-Azhar, for the primary and secondary education, where he often became top of his class (Soage, 2008). Besides academic excellence, he was interested in Arabic literate. He read all the renowned writers in that time and wrote poetry that he generally selected to recite the verse of his own poem (Wardeh, 2001: 8). In Tanta, al-Qaradawi came closer to the Muslim Brotherhood (MB), which began by listening to the founder of the movement Hasan al Banna, at an event hosted by local MB. Within involvement with MB, he was prisoned for three 
times; firstly, in the year of 1949 at the time of Tanta; secondly, between 1954-1956 and thirdly, in the year of 1961 (Wardeh, 2001: 16).

After graduated from Tanta, he traveled to Cairo for Al Azhar. He enrolled in the Faculty of Usulal-Din of Al Azhar University. In 1953, he matriculated with the graduate diploma (as Shahada al-Aliyah), obtaining the highest mark in his year (Wardeh, 2001: 9). He graduated in 1954 and secured first position among 500 students in the department of Arabic language in 1968 (Gräf and Skovgaard-Petersen, 2009; Haji Mohamad, 2015: 48). In 1957, he obtained another diploma in language and literature from the graduate institute of Arabic studies. Following this, in 1960, he completed his Master degree in the Quran and Sunnah science from the Faculty of religious science. In the same year, he enrolled in the Ph. D. program, though he couldn't complete the degree before 1973 because of political problems. His Ph.D. thesis was Zakat and its effect on solving social problems. In the short time career in Egypt after completing the university degree, he worked as a writer, publication advisor at the department of Islamic culture at Al-Azhar, an Imam and a lecturer in several mosques, supervisor of the Institute of Imam under religious ministry (Haji Mohamad, 2015: 48).

The turning point for his career was to migrate to Qatar. Though he started his career as a principal in a secondary-level institute of religious studies in Doha, he became the most influential person within a short time. His works as preacher orator influenced Qataris, especially Qatar's former emir, Khalifa bin Hamad al-Thani who offered him a Qatari citizenship in 1968 (Gräf and SkovgaardPetersen, 2009; Haji Mohamad, 2015: 48). In the period from the 60s to the 70s, al-Qaradawi played a central role in shaping Qatar's religious education. After completing his Ph.D. in 1973, he was appointed as the head of the Department of Islamic studies in the Faculty of Education, now the University of Qatar. In 1977, he established the Faculty of Sharia and Islamic studies and the center of Seerah and Sunnah Research. He served as a dean of the Faculty until 1990 (Haji Mohamad, 2015: 48).

At the same time, he got fame as an international scholar. He used modern technology, the internet, and media for preaching. His most successful television program, Sharī’a wa al-Ḥaya (Sharia and Life), started to broadcast on the Qatari channel Al-Jazeera in 1996 and became a popular program worldwide, especially among the Arabic spoken people. In 1997, he initiated a website in his name (www.qaradawi.net) and another Islamic website is now known as "OnIslam" (formerly "IslamOnline"), are serving as an extensive resource for Muslims seeking scholarly opinions on issues relevant to Islam, current Muslim news and events, and various forms of Islamic information such as sermons, Qur'anic texts, and Hadith collections. He initiated several international organizations, research organizations, Islamic banks, and community organizations. International Union for Muslim Scholars (IUMS) is one of these initiatives and served as a president of this union (The Milli Gazette, 2014).

Al-Qaradawi is the author of hundreds of books, articles, commentaries and research papers 
dealing with various aspects of Islam- such as Islamic jurisprudence, fundamentals of religion, Islamic economy, Qur'an, hadith, education, Islamic revival, and Islamic thought - many of which have been translated into several languages including Albanian, Bosnian, Bangla, Dutch, English, French, German, Hindi, Urdu, Spanish, and Turkish. Among his most popular books are The Lawful and the Prohibited in Islam, Fiqh az Zakat: A Comparative Study: The Rules, Regulations, and Philosophy of Zakat in the Light of the Quran and Sunna, Priorities of the Islamic Movement in the Coming Phase, Islamic Awakening: Between Rejection and Extremism.

In the thought of al-Qaradawi, there is a huge influence of contemporary Islamist intellectuals, especially Hasan al-Banna and Abul Al'a Maududi. He often quoted from al-Banna in his books. As mentioned before, he engaged himself with the Muslim Brotherhood and later worked as a theorist of this movement. He even offered to the post of general guide or head (Murshid alA'am) of Muslim Brotherhood though he refused it (Warren, 2014: 60). His thought was often distinguished as a moderate (wasatiyya) thinker following the path of Muhammad Abduh and Rashid Rida. He criticized extreme thought and worked for normalization of thinking; as Warren (2014) argued, he was closely involved in the initiative of Muslim Brotherhood leaders to move it away from the violent stream that were associated with the writings of Sayyid Qutb (Warren, 2014: 49). From classical theorists, he was influenced by and often quoted from Imam Ghazzali, Ibn Taymiyyah, and Ibn al-Qayyim.

\section{A Wise Political Fiqh of Islamic state: The Political Thought of Yusuf al-Qaradawi}

Yusuf al-Qaradawi discussed his thought on state in the book State in Islam (Min Fiqh al-Dawla fi'l-Islām). Within five different chapters, he broadly discussed the Islamic state's feature and several important contemporary issues regarding the Islamic state. He intended to distinguish his political thought, mainly focusing on "wise political Fiqh," discussed in chapter four. Within this wise political thought, he featured an "Islamic State" in Modern time that accepts the Modern concept of State, especially from Western political thought, if it is not against Islam's norms and values. His targeted audience was basically from the Islamic movements, as he advised them in several chapters of the book. Here, it will be discussed broadly:

\subsection{Negative Political Fiqh Phenomena}

At first, al-Qaradawi intended to identify some negative political understandings of different political and intellectual groups, which he mentioned as negative political 'Fiqh' in his book. Firstly, he distinguished Islamic awaking groups in general and Islamic movements in particular who are in negative and dangerous thinking, especially in the political field and political thought. He claimed that because of wide-spread trials and brutal clashes on Islamic Movement since the fifties and sixties of the 20th century, the negative and dangerous thinking which al-Qaradawi named as 'ideology of trial' or 'Fiqh of Trial' has emerged. According to him, "this ideology was vividly flowing, yet irregular, stigmatizing the society with 'disbelief', looking at people and life through a black glass which further went so far as to isolate its advocates from society as being 
superior in rank above it" (al-Qaradawi, 2004: 109). Al-Qaradawi claimed that this thinking still has a resounding effect on many of the leaders and writers of the Islamic movement also has an effect of the literature of Da'wah, education, and political oriented writings. Al-Qardawi minded that the Islamic movement must break through the ideology and Fiqh of Trial. Instead of this thinking 'the ideology and fiqh of well-being', there should be initiation to deal with the people, life and the World.

Secondly, he is concerned about 'Zhahiri ideology' or 'Zhahiri Fiqh', which is adopted by so-called new Zhahirists and confines itself to more words of the texts and doesn't delve into the objectives of legislation nor pay ahead to the people's interests. He stated that the scholars stressed the fact that the Islamic judgments (Ahkam) were not ordained except to meet the interest of people in this life and the Hereafter. Before mentioning his own opinion, he quoted from Imam Ibn al-Qayyim,

"Any judgement that leads to corruption rather than meeting the interest of people, that leads to injustice rather than justice, or to cruelty rather than mercy or to folly rather than wisdom must not be attributed to the Shari'ah, even by way of misinterpretation" (al-Qaradawi, 2004: 110).

Al-Qardawi, in his opinion, intended to say that this ideology may be accepted in individual level in certain rituals and judgment but cannot accepted in the field of as-Siyasah Ash-Shar'yah (politics governed by Shari'ah), which deals with general people as both Muslim and non-Muslim, the East and the West, the times of power and weakness. He stated that politics should be governed by comprehensiveness and flexibility, balance and preponderance, and paid due consideration to the change of time and place as well as man himself.

Thirdly, he concerned about 'Khariji ideology' or 'Khariji Fiqh' which follows in the way of the ancient Kharijites who are infamous for their narrow-mindedness towards religion and life, strictness in treating others and rejection, accusation and evil thought they are known for their sincerity and courage about their Fiqh. In addition to this, they stick tenaciously to their own viewpoint in any situation. Al-Qaradawi included that some Islamists also thinks of Khariji's thought.

Fourthly, he is concerned about 'Traditional Ideology' or 'Traditional Fiqh' which seeks a solution to every problem that deals with thought, politics, or legislation in the books of the modern scholars with the text of traditional fiqh. Al-Qaradawi claimed that this Fiqh didn't intend to go beyond their instruction, nor perceived the Shari'ah in its broadest scope with the different schools. It didn't consider the reality of the age in the light of its trends and problems. He stated that it had made the Shari'ah as limited and difficult where Islam has made it easy.

\subsection{A Wise Political Fiqh}

Mentioning the above negative understanding, al-Qaradawi intended to distinguish the wise or positive political Fiqh. He advised the Islamic Movements and the Islamic Awaking groups to approach a new political fiqh to overcome these passive phenomena and their effect on Muslims. 
He included that the new Fiqh will approach Fiqh of Sunan, Fiqh of Targets, Fiqh of Balance, Fiqh of Priorities, and Fiqh of Difference (al-Qaradawi, 2004; 111). For generating such kind of Fiqh, al-Qaradawi paid his attention in the following matters:

\subsubsection{Deficiency in Political Fiqh should be Treated}

Al-Qaradawi warned the Islamic Movement and Islamic Awaking to treat the deficiency of thought as strange concepts, extraordinary judgments, or deduction methodologies for building a new Fiqh. He claimed that in the early years, 'political ideology' and 'political fiqh' have not received importance within research as much as the Fiqh of worship, transactions, and marriage, etc. So, there are a lot of misconceptions regarding this Fiqh among Islamic callers.

He mentioned some examples: as some scholars consider that Shura (consultation) is not obligatory, the head of the state has the right to proclaim the war without consulting with Shura. Some people mind that following the democratic process is similar to disbelief or leading one to disbelief. Some people think that women have no role in national politics. Within this way, some people reject the multi-party system in the Islamic state, and so on.

Qarawai claimed that these people are mixing up matters of deeds (A'mal) with faith (Aqidah). He mentioned that the matters of deeds are related to as-Siyasah ash-Shari'yyah, in which the Mujtahid is rewarded twice if he is right and once if he is wrong. So, it is needed to identify the deficiencies in political Fiqh with such kind of misconception.

\subsubsection{Case Study: Setting a Specific Term of Office for the President}

Al-Qardawi intended to mention a practical example as a case study of their claim where he questioned a person who believed that setting a specific term of office for president is unlawful (Haram) even if it is in the interest of Muslims. That people answered to al-Qardawi as quoted in the book:

"Ever since the Caliphate of Abu Bakr (may Allah be pleased with him) no Caliph has been chosen for a specific length of time; all of them rule for life. Moreover, the Prophet (peace be upon him) ordered us to stick firmly to their way according to the hadith that reported on the authority of alIrbad ibn Sariyah. In this hadith the Prophet (peace be upon him) warned us against evil innovation as falsehood and this limited term for presidency is one of these innovations" (al-Qardawi, 2004: 114).

Here al-Qaradawi's arguments are important to discuss for building a wise political Fiqh. Firstly, he mentioned that Allah ordered to follow in the Prophet's footsteps who has priority in being followed rather than the Rashidun Caliphs. For his, Sunnah is the second source of Shari'ah from which Islam flows. The Sunnah, together with Allah's book, is the first reference to settle differences and controversy. He mentioned the hadith of al-Irbad, where Prophet said, "Follow my Sunnah and follow in the footsteps of the Rightly Guided Caliphs" (al-Qaradawi, 2004: 114) and 
stated that here also Sunnah takes priority and preference in being followed.

Al-Qardawi argued that Sunnah, which includes the Prophet sayings, actions, and approbation as both but the action of Prophet, are not judged as obligatory instead as permissible and lawful unless cemented by other evidence that boosts preference or obligation. He mentioned that in some cases, caliphs did something other than the Sunnah when it conflicted with the current interest of Muslims. For instance, al-Qaradawi mentioned Hazrat Umar's decision about Iraq's war booty, where he didn't distribute these booties among warriors. However, Prophet distributed this booty among warriors in the Khaybar Battle after the enemy was defeated. Umar's companions argued with him and tried to convince him that he has violated the superficial interpretation of the chapter al-Anfal's verse where Allah provided a particular way to distribute the booty of war. Umar defended his judgment by saying;

"I saw that the war booty was more enough to be exploited for the benefit of this generation and the next one... Do you want future generations to blame us for not leaving them anything that can make their lives honorable and easy?" (al-Qaradawi, 2004: 115).

Al-Qaradawi mentioned that Hazrat Umar considered the interest the forthcoming generation and make his judgment based on another text of the Quran, by chapter Al-Hashr where Allah stated; "And (the ones) who came even after them" (al-Quran, 59: 10 as mentioned al-Qaradawi, 2004: 115). Al-Qardawi mentioned the argument of Imam Ibn Qudamah on this issue, who stated that the Prophet's and Umar's judgment was based on observing what was in the best interests of Muslims under the existing circumstances and time (al-Qaradawi, 2004: 115).

Within this example, al-Qaradawi intended to discuss the essential principles of political Fiqh; firstly, any pervious practice on a particular issue do not automatically prove its legislative obligation because Prophet's action, which is inseparable from his Sunnah, is not obligatory for his followers and his companions did not hesitate to go against it to fulfill their present condition or specific observations; secondly, in choosing rules and laws it is necessary to consider the best interest of current time, environment and circumstance with considering overall text for ensuring a flexible Shari'ah, as al-Qaradawi mentioned,

"Choose the rules and laws that suit and are in the best interest of our time, environment and circumstances, in the light of overall texts and objectives of the flexible Islamic Shari'ah" (al-

Qaradawi,2004: 116).

\subsubsection{The Sunnah and Innovation}

A second objection on fixing a specific 'term' for president came from the group who considered it as innovation (bid'ah). They argued that all types of innovation are falsehood and evil, according to the Quran, Sunnah, and consensus. Al-Qaradawi argued that innovation is falsehood when it deals with absolute religious matters as faith, worship, and the like but innovations that deal with customs, habits, and administrative, social, educational and political affairs is not falsehood which 
was fixed as 'evil' by Shari'ah. He mentioned the argument of Imam ash-Shatibi, who regarded this type of innovation as 'Public interest'. Al-Qaradawi further argued by mentioning the activities of companions of the Prophet after him, which he didn't do so. As he mentioned,

"The companions did things which prophet (peace be upon him) did not do such as compiling the Qur'an in one volume, writing down the accounts, imposing khiraj and building prisons.

In the same way, the followers did things that the companions did not do such as mintage, organizing mail service and others" (al-Qaradawi, 2004: 117).

Al-Qardawi forwarded with remembering the actions of Umar ibn al-Khattab, who accomplished a considerable list of things which were at that time unprecedented, which were granted consensus and have been followed ever since. He mentioned the hadith of the Prophet where he announced a reward for inventing good Sunnah as,

"Whoever invents a good Sunnah will be rewarded for inventing it and will be rewarded every time a Muslim follows it until the Day of Judgment” (al-Qaradawi, 2004: 117).

\subsubsection{The Wrong Behind the Absolute Dependence on the Biography of the Prophet}

Here al-Qaradawi intended to identify a principle of political Fiqh as the Prophet biography (Sirah) is not similar to Sunnah. He mentioned that one of the fundamental errors in the political Fiqh is mixing Sunnah with the Prophet's biography when seeking evidence and proofs. He explained that Sunnah is the source of legislation and Islamic orientation besides the Quran, where the Quran is the source, and basis and Sunnah is the interpretation, explanation, and application (al-Qaradawi, 2004: 118).

Before mentioning his argument regarding Sunnah and Prophet biography, he discuss two perspectives of this issue; firstly, the scholars of the Principles of Islamic jurisprudence who excluded the Prophet biography in the definition of Sunnah; secondly, the scholars of Hadith who added Prophet's words, actions, and approbations- the physical and moral description and the Prophet's biography where it was a less important matter whether it had anything to do with legislation or not. They narrated whatever happened in the life of the Prophet. Within Hadith, a group of people argued that the biography of the Prophet is also the part of Sunnah.

Finally, he argued in this issue within two important points; firstly, many incidents in the Prophet's biography are narrated without mentioning an authentic authority and the scholars were not scrutinizing the accuracy in narration as the accuracy in the narration of the hadiths were scrutinized that deal with lawful (Halal) and unlawful (Haram); secondly, the Prophet's biography represents the practical side of his life which is same as the 'action' of his life and 'action' does not denote obligation. He tries to explain it in more detail by mentioning the verse 21 of the chapter al-Ahzab, where Allah orders to follow his Prophet, as mentioned:

"Indeed you have already had a fair example in the messenger of Allah for whosoever hopes for Allah and the Last Day, and remembers Allah much" (al-Qaradawi, 2004: 119). 
Al-Qaradawi argued that this verse urges one to imitate and follow his example. Yet, it does not indicate that it is obligatory and following his way means to follow his morals, values, and general conduct, other than following minute details. He included that it is unnecessary to follow his example in his secret call (Da'wah) to Allah's way and Islamic Monotheism (Tawhid) unless the circumstances necessitate it. Similarly, the migration for Medina, which was obligatory in a time and no longer obligatory after the Mecca conquest or it not necessary to seek the help of powerful and influential people like Aws and Khazraj.

\subsection{Feature of an Islamic State through Wise Political Fiqh}

Within the above discussion, it is clear that al-Qaradawi intended to generate a positive political Fiqh from several aspects. His text on state, which he wrote in another chapter in the book, will be discussed. At first, he intended to prove the existence of the Islamic state in all-time. Later, he discussed the nature of the Islamic state and construction of Islamic state. Finally, he focused on some contemporary issues of Western thought to relate that issue with Islamic political thought.

\subsubsection{Status of State in Islam}

Al-Qaradawi targeted the secularist scholars who claimed that Islam has nothing to do with politics or Islam is all about religion, not politics. Mentioning the proofs from text (Quran and Hadith), Islamic history, and the nature of Islam, he intended to prove that Islam has a state concept that deals with all aspects of the Modern state. He mentioned the several verses of the Quran, where God directed the ruler and ruled. So, without the presence of state, these verses would be meaningless. He mentioned several hadith of prophet related to the aspect of the state. He mentioned the books of classical Muslim authors which wrote on imamate and caliphate such as Al-Ahkam as-Sultaniyyah by al-Mawardi and like by Abu Ya'al, Al-Ghayathi byImam Al-Haramayn, As-Siyasah AshShar'iyyah by Ibn Taymiyah, Tahrir Al-Ahkam by Ibn Jama'ah, al-Kharaj by Abu Yusuf, and the like by Yahya ibn Adam, al-Amwal by Abu Ubayd and like by Ibn Zanjiwayh. He mentioned the political existence of Muslims in Medina, which holds all of the conditions of the state, and it was continued by Caliphate Rashidun, Umayyad, Abbasid, and Ottoman. Finally, he argued from the nature of Islam where Islam instructs to elect a leader during travel even if it only by three people. When it is performed in a congregation, the daily prayer is not accepted without a leader (Imam). Along with this scenario, a lot of practice in Islam is not possible without a state or state power, for example; performing pilgrimage (Hajj) and Friday prayer (Jum'a) or Eid prayer, and participating Jihad, establishing justice (Insaf), helping oppressed people, implementing hudud (punishment of most egregious crimes) which all are the important jurisdiction/part of Sha'ria.

Further, he also targeted the scholars who coined the term "political Islam" for dividing the activities of Islamic movements from other Muslims. He argued that Islam must be political, and the Muslim character is a political one. Because forbidding evil is an obligatory part of a Muslim's life or resisting corruption and oppression is necessary. He indicated that all of these duties are the collective duty for Muslims. 


\subsubsection{Construction of State within Islamic Resource}

Al-Qaradawi argued that the Islamic state is a civilian state whose recourse is Islam. Qaradawi included that the rulers of an Islamic state are selected from strong, trustworthy, defenders, and knowledgeable citizens. It is not a correct choice to select anyone who lacks these qualities without dire necessities. By mentioning these qualities, al-Qardawi probably intended to indicate that, for being a ruler of the Islamic state, it is unnecessary to become religious people (Ulama) like other communities, especially the Christian Churches in the Middle Ages practiced.

Al-Qaradawi further argued that it is a global state based on Ummah rather than a territorial or ethnics state. He explained that the Islamic state is not limited to tribal boundaries or geographical border rather than a global state with universal massages based on a concept and belief. It is an open state for believers based on free choice and without any type of coercion. There is no difference between its citizen-based on ethnicity, nationality, language, and color. The state is based on Tawhid (oneness of Allah), where the people of one faith, one prophet, one Qiblah, one book, one ceremony, one law or constitution, and one culture. This global state may be initiated from a single territory, as al-Qaradawi mentioned,

"Nothing can stop this global state from starting in a region as a territorial state. Its members can choose Islam for their constitution, and its application for creating an Islamic model upon earth. In this regard the Islamic state faces clandestine and open wars, material and spiritual

restrictions or sanctions. Only people of strong will can be patient. In different territories different models will appear, bringing about a united state based on unity and cooperation (federal or confederate)" (al-Qaradawi, 2004: 38).

Al-Qaradawi further included that the Islamic state is a constitutional state. The regulations of this constitution are derived from Qur'an and Sunnah for its all aspects as faith, worship, ethics, criminal, administrative, judicial, and international matters. Al-Qaradawi argued that the Islamic state would exist until it follows the Islamic Law. If it exits from Islamic law, people are not bound to follow it. Islamic state hasn't any power to draft any law without the procedure of the Quran and Sunnah. Al-Qaradawi mentioned that there is no particular shape or name that can be applied in the Islamic state. He mentioned from Islamic history that only two terms with significant meaning have been used; Imamate and caliphate.

Al-Qaradawi further argued that the Islamic state is not a monarchial one where it is founded on heredity lines, which restricts the office of authority to one family or one branch from which sons inherit their rule from their fathers and grandson from their grandfathers. Islamic state is founded based on the consultative feature (Shura), which is an essential principle of democracy but not the same or a copy of Western democracy. In Islam, it is agreed that a nation should be given the right to choose its ruler without any type of force. It also adopts the stand that the ruler is responsible before the state's representatives of consultation who have the right to dismiss the ruler if he deviates and oppresses them. 
Al-Qaradawi mentioned the Indian scholar Abu Al-Hassan an-Nadawi's description of the Islamic state and stated that Islamic state is a state of guidance, not a tax collection state. He included that the Islamic state's ultimate concern is to spread its call to all humanity and communicate its mission everywhere.

Al-Qaradawi included that the Islamic state safeguards of the weak instead of the interest of the powerful one. It imposes Zakah upon the rich to compensate the poor. It further specifies a particular portion of the state's resource for the needy, the orphans, and the wayfarer.

Along with these characteristics of the Islamic state, al-Qaradawi also mentioned that the Islamic state is a state of liberties, rights, law, principles, and moralities.

\subsubsection{Islamic state is a Civilian One rather than Divine State}

As the researcher mentioned before that al-Qaradawi argued the Islamic state is a civilian state, here it is intended to discuss elaborately on this issue. Al-Qaradawi targeted the scholars who claimed that the Islamic state is a divine state by mentioning several examples/ incidents from history. He argued that there is vast difference between Islamic state based on Islam and the theocracies of the Christian West in the middle ages. He mentioned that Islam is more comprehensive than the term 'religion'. He stated the arguments of scholars of al-Usul (Principles of Islamic Jurisprudence), where they identified 'religion' as one of the five or six necessities that Shari'ah seeks to preserve, including religion, souls, intellect, offspring, and property; however, some added honor. He mentioned that it is a big mistake to think the Islamic state is based on theology alone. He argued that the Islamic state is a civilian state based on choice, agreement, and consultation. The ruler is accountable before his people, and everybody has the right to advise his ruler and asks him to do right or give up doing wrong. He included that Islam considers this type of conduct a duty for Muslims collectively or individually.

Al-Qaradawi further argued that the ruler is not unrestricted; he is controlled by Shari'ah, directed by values, and restricted by rules where he, his party, or his servants can't have any influence. The lawgiver is God, and nobody has the right to change it. Any Muslim has the right to disobey the ruler if he is in apparent disagreement with Allah's jurisdiction and law. Muslims also must disobey in that situation. Al-Qardawi put several hadith and example in favor of this argument.

\subsection{Islam State and democracy}

Al-Qaradawi started his discussion on democracy by raising the question, can democracy be an evil-doing or an expression of disbelief? To mention his concern to democracy, firstly, he intended to answer the question by mentioning the definition of democracy. According to him, democracy is,

"People must choose their ruler by themselves. No ruler or regime to be forced upon them without their full consent. They must have the right to bring him to account if he commits a mistake. 
Moreover, they must have the right to depose him and choose a new ruler if he goes astray. People must not be led against their will to advocate economical, social, cultural or political trends and programs that they are not satisfied with. And, if some of them opposed the regime, they must not to be exposed to expulsion, exemplary punishment or the worst of torture and massacre. In sum up it embodied in election, public opinion poll, preference of the majority rule, multi-party system, the right of minority opposition, freedom of the press and the independence of jurisdiction.....etc" (al-Qaradawi, 2004: 194).

Al-Qaradawi now compares the content of democracy with Islamic norms and values of government. He argued that the content of democracy does not oppose the values and norms or practices of Islam. He mentioned that Islam warns one against leading a group of people while his followers dislike him. The Qur'an lunched hard attacks on half-god on earth that enslave Allah's slaves in the several verses, such as Namrud. The Sunnah also attacked the oppressive ruler. On the other hand, Shura (consultation) is the basis of the Islamic state. He stated that Islam has made Shura as obligatory from both sides, on the ruler or governor to consult his nation and on the nation to give advice to the ruler.

Al-Qaradawi also included that Islam considers the ruler as the deputy or servant of people. It gives the nation every right to hold him accountable for his deeds and take away his powers if he abuses his influence and fails to fulfill his commitments. Most importantly, the ruler is not above suspicion, censor, and punishment; he is a vulnerable human being like other people who can be right or wrong. He put several examples from the Rashidun caliphate, encouraging people to advise them and advise them.

Within this perspective, al-Qaradawi stated the advantages of democracy as it has a long history of struggle with tyrants, oppressors, kings, and princes, which have built some formulas and methods that are regarded as the best guarantees to protect people from oppression and injustice of tyrants in present days. Though it has several shortcomings and defects as a man maid system, it is the best government system in contemporary time. Now al-Qaradawi stated his final argument on this issue. He argued from al-Usul,

"It is legally admitted that what pertains to a duty is a duty in turn and that the legal ends that require specific means grant the means the legality of the ends and there is no legal objection to adopting a theory or the idea initiated by non-Muslim (as long as it promotes the public interest of Muslim)" (al-Qaradawi, 2004: 204).

He put the examples of adopting non-Muslims ideas in the Prophet's time as the digging a trench during the battle of Ahzab, which was originally a Persian idea or the teaching project by nonMuslim captive for Muslims youth after the battle of Badr.

Later al-Qaradawi opened his discussion on some specific components of democracy claimed as unlawful (Haram) or the opposite of Islamic practice by Ulama. Firstly, he considered elections 
and polls as a certificate of validity and credibility to the candidate. He argued that in justice it is common to accept such kind of certificate for being innocent or guilty. He also argued that the voters also need to be endowed with justice and have a good reputation.

In further discussion, al-Qaradawi targeted the scholars who claimed that democracy is based on people's rule, which is against the bases of Islamic trends as only Allah's rule that why democracy is not acceptable in Islamic thought. Here he again urged to follow positive Fiqh rather than negative Fiqh promoted by the oppressors and sinful king or rulers, nor to the fatwas of the lost and deluded scholars of sultans, nor the over-enthusiastic and rash devoted Muslims who are not firmly grounded in knowledge (al-Qaradawi, 2004: 207).

Al-Qaradawi argued that the bases of democracy on the principle of the people's rule, which does not contradict the principle of Islamic jurisdiction, that only Allah has the right to introduce legislation, rather it runs counter to the principle of the individual's rule on which dictatorship is based. He argued that by the "role is only for God" means two specific meaning; firstly, God as regards the universe and destiny not for legislation and decrees; secondly, Allah's rule as regards legislation and decree is one of assignment of duties, enjoining, forbidding, obligation and choice. Further a true Muslim couldn't reject the obligation of lawful (Halal) and the unlawful (Haram), which are fixed by God (al-Qaradawi, 2004: 207).

Further, he paid his attention to the issue, majority's judgment/rule is against Islam? which is a basic principle of democracy. He intended To respond the claim who minded that majority's judgment is not allowed in Islam. Firstly, he argued that the majority is a valid preponderant factor because it is a common sense that Islamic law and reality necessitate the presence of an impetus that will scale decision making (al-Qaradawi, 2004: 213). Controversial issues are all-time settled by the judgment of the majority of people. Al-Qaradawi quoted from hadith, where Prophet mentioned, "If both of you agreed on a single advice, I would not have acted against it" (al-Qaradawi, 2004: 214).

Later al-Qaradawi put several examples from the Prophet's time where the judgment of the majority was accepted, as the battle of Uhud where the Prophet accepted to march to meet the disbelievers according to the opinion of the majority though his initial opinion was to stay in the medina and fight disbelievers there.

\subsection{Pluralism in Islamic State}

Al-Qaradawi argued that there is no legitimate prohibition to the existence of more than one political party in an Islamic state because such a prohibition needs a Devine text, of which there is none. On the contrary, Their existence necessary for advising, correcting the ruler. He considered the multi-party system in politics as the diversity of schools of thought in Fiqh. Al-Qaradawi put two conditions to legitimize their existence;

“(1) they must acknowledge and respect Islam as a creed and jurisprudence and not oppose or deny it even if they have their own judgements and understanding of it in light of admitted, scientific 
rules: (2) they must not work for any hostile force against Islam or the nation, regardless of its identification or whereabouts" (al-Qaradawi, 2004: 222).

Qaradawi considers multiplicity is an essential force for correcting the ruler or ruling parties activities not to become oppressors. Finally, he argued that Hazrat Ali accepted the Khawarij party's existence, where they opposed him.

\section{Findings and Conclusion}

Within the above discussion on al-Qaradawi's political thought, it is apparent that he intended to develop a positive political Fiqh for conceptualizing an Islamic state in contemporary time. He rejected the aspects of negative Fiqh and advised to follow the overall text for conceptualizing any term concerning the present situation and environment. He intended to consider overall Sunnah as a priority on the biography of the prophet in terms of legislation when it functions with the mass people as Usul al-Fiqh (principle of Islamic jurisprudence) directed. He stated that innovation (bid'ah) is only applicable when it deals with matters of faith (Iman) and action (Ibadat). And it is not applicable when it deals with regular life; instead, it is necessary (innovation) to lead the regular social life. In developing the state's concept, he was more flexible in accepting Western thought, particularly the terms which are not opposed to the Islamic norms and values. He didn't follow the way of the traditional scholar who thinks that whatever comes from non-Muslim is unlawful (Haram). He mentioned here several arguments to prove that any system generated by non-Muslim is lawful (Halal) if it does not oppose the norms of Shari'ah. In his perception of the state, the Islamic state is a civilian state which will construct according to Islamic norms and values rather than a divine state leading by traditional Ulama. He considered the Islamic state is a global state based on Ummah, but he agreed the beginning of it with a nation-state. Qaradawi considered the Islamic state a mass state rather than a monarchical one where Shura is obligatory, not an option. He accepted democracy as a means for establishing an Islamic state. He compared it with the digging a trench during the battle of Ahzab, which was originally a Persian (non-Muslim) idea. He considered it the best means of opposing tyrant and oppressors in Modern time with its long practice system and formulas.

Finally, al-Qaradawi's political Fiqh is important to conceptualize the Islamic state in the contemporary World. Especially for settling controversy and extremism all over the Muslim countries. From al-Qaradawi's political Fiqh, it is apparent that he is concerned about the current situation, circumstance, and environment. As he practically observed the situations in the 50s and 60s, especially in Egypt, the trail, and the oppression, he intended to conclude that there is no benefit of negative thinking and extremism. Instead of that, a positive understanding may change the situation. Thus, he urged to become flexible and think extensively in public matters, especially in the politics and state. As Wardeh also argued, "al-Qaradawi had constructed a personal vision of Islam as a comprehensive, universal way of life" (Wardeh, 2011: 21). So, al-Qaradawi intended to find a balanced way to argue the state's concept within positive political Fiqh. 


\section{REFERENCE}

Al-Qaradawi, Yusuf (2004). State in Islam, Al Falah Foundation, Cairo

Baroudi, S. E. (2014). Sheikh Yusuf Qaradawi on International Relations: The Discourse of a Leading Islamist Scholar (1926-). Middle Eastern Studies, 50(1), 2-26.

Bartal, S. (2015). Sheikh Qaradawi and the internal Palestinian struggle issues preventing reconciliation between Fatah and Hamas and the influence of the Qaradāwi Era over the struggle between the organizations. Middle Eastern Studies, 51(4), 585-599.

El Mahdy, R. A. (2015). The compatibility of Yusuf Al Qaradawi's wasateyya school of thought with the second generation of the Muslim Brotherhood.

Elo, S., Kynga, S.H. (2008). The qualitative content analysis process, Journal of Advanced Nursing 62(1), 107-115

Gräf, B. and Skovgaard-Petersen, J. eds., 2009. Global Mufti: The Phenomenon of Yūsuf alQarad̄āwi. New York: Columbia University Press.

Haji Mohamad, M. A. B. (2015). European Islam and reform: a comparative study of the theologies of Yusuf al-Qaradawi and Tariq Ramadan (Doctoral dissertation, University of Birmingham).

Krippendorff, K. (2004). Content analysis: An introduction to its methodology (2nd ed.). Thousand Oaks, CA: Sage.

Soage, A. B. (2008). Shaykh Yusuf al-Qaradawi: Portrait of a Leading Islamic Cleric. Middle East Review of International Afairs, 12(1), 51-68.

The Milli Gazette (2014). Qaradawi re-elected as President of International Union of Muslim Scholars, https://www.milligazette.com/news/12-special-reports/10890-qaradawi-re-electediums-president-international-union-of-muslim-scholars/ (Last accessed: 12.09.2020)

Wardeh, Nadia (2001). Yuauf al-Qaradawi and the "Islamic Awakening" of the late 20th Century, Masers' thesis paper, Faculty of Graduate Studies and Research, Institute of Islamic Studies McGill University, Montreal

Warren, D. H. (2014). Debating the Renewal of Islamic Jurisprudence (Tajdīd al-Fiqh) Yusuf alQaradawi, his Interlocutors, and the Articulation, Transmission and Reconstruction of the Fiqh Tradition in the Qatar-Context, Doctorate thesis, Faculty of Humanity, School of Arts, Languages and Cultures University of Manchester, England

Warren, D. H. (2014). The 'Ulamā' and the Arab Uprisings 2011-13: Considering Yusuf alQaradawi, the 'Global Mufti,'between the Muslim Brotherhood, the Islamic Legal Tradition, and Qatari Foreign Policy. New Middle Eastern Studies, 4. 